\title{
An Empirical Study on the Satisfaction Level of Women Lawyers towards Their Work Life Balance
}

\author{
P. Kannan \\ Assistant Professor, Department of Mechanical Engineering, Vetri Vinayaha College of Engineering and \\ Technology, Tholurpatti (Post),Thottiyam(Taluk), Trichirappalli (District), Tamilnadu, India -621215
}

\begin{abstract}
Legal profession is one of the growing and lucrative professions all over the world. It is one of the most adventurous as well as exciting career. Lawyers are held in high esteem in our society, and there remains the faith that when all else fails, one can still take recourse to the legal system. In such a valued profession women doesn't occupy a valuable space. Though participation of Women in legal profession has grown in the recent years, women were not given equivalent power and opportunities. Less frequently given the opportunity to move onto the occupational fast track, women face subtle but often self-perpetuating cycles of gender bias that limit their career choices. Although women qualify in equal proportions to men at the entry point of professional courses, there is a progressive decline in the number of women as one move up the hierarchy. Our legal structure should be modified wherein women are encouraged to get into legal profession and gender specific issues are to be eliminated in order to reduce the attrition rate of women lawyers.
\end{abstract}

Keywords: Women lawyers, Satisfaction level, work life balance

\section{Introduction}

The history of the legal profession in India can be traced back to the establishment of the First British Court in Bombay in 1672 by Governor Aungier. The Supreme Court of Judicature was established in Calcutta in 1774. Similar Supreme Courts were established in Madras in 1801 and Bombay in 1823. India has the world's second largest legal profession with more than 6,00,000 lawyers. There were six grades of legal practice in India after the founding of the High Court's - a) Advocates, b) Attorneys (Solicitors), c) Vakils of High Courts, d) Pleaders, e) Mukhtars, f) Revenue Agents. The Legal Practitioners Act of 1879 in fact brought all the six grades of the profession into one system under the jurisdiction of the High Courts.

The path of women in the legal profession can very easily be described as a process of continuing challenge. Even in India, where women were given political rights such as the right to vote and the right to contest elections at the same time as men, a hard battle had to be waged for women to be able to practice as legal professionals. Anna Chandy from Kerala became India's first woman judge in 1937. She was promoted to the Kerala high court in 1959, the first woman judge to make it to a high court.

\section{Objectives Of The Study:}

1. To study the gender - specific issues involved in legal profession.

2. To study the problems faced by women in legal profession.

3. Work - life balance of women in legal profession.

\section{Literature Review:}

Law is the principle and regulations established in a community by some authority and applicable to its people, whether in the form of legislation or of custom and policies recognized and enforced by judicial decision. Law can be any written or positive rule or collection of rules prescribed under the authority of the state or nation, as by the people in its constitution.

\section{Gender Bias In Legal Profession:}

Gender bias in the profession is reflected at several levels:

First, in the proportion of women lawyers;

Second, in the attrition rate of women advocates, and

Finally, in the lack of high positions that women lawyers occupy be it in the bar, in law firms or in the judiciary.

According to a 2009 report by the National Association of Women Lawyers, women are grossly underrepresented in leadership roles in the legal profession. Despite their widespread presence in the profession, and their numerical gains, they are yet to achieve equivalent increases in power and opportunities. Women now comprise more than a quarter of the legal profession and about half of all law students, but their numerical gains have not yielded equivalent increases in power and opportunities. Within the legal departments significant 
gender differences exists regarding current position and salary. Gender inequalities persist across legal education, hiring, remuneration, promotions, and other professional opportunities in law.

\section{Problems Faced By Women In Legal Profession:}

Sexual harassment is a problem that women lawyers have encountered almost since the start of their practice. The number and proportion of women lawyers who are leaving the practice of law significantly exceeds the number and proportion of men lawyers who are leaving, sexual harassment is one of the main reasons for this attrition rate of women lawyers.

\section{Work Life Balance of Women Lawyers:}

The biggest challenge for women lawyers across countries and types of legal practice is undoubtedly balancing their domestic duties with their professional demands. While it can be said that balancing their homes and work is a challenge for women in all professions given that the burden of domestic duties invariably falls on the woman, what makes it especially challenging is the fact that the legal system is engineered from the point of view of men.

An important new finding of a research is that women lawyers often choose an exit strategy when faced with the dilemma of choosing between work and family obligations. Women lawyers leave their jobs more often than men, because women lawyers have more family responsibilities.

\section{Research Methodology}

The research tool used for this study is questionnaire. Where I part of the questionnaire contains the demographic details like age, work experience, income etc. Part II includes questions related to gender specific issues in legal profession. Gender specific issues, were assessed on a five point Likert type scale ranging from 1 $=$ "strongly disagree" to $5=$ "strongly agree". And the final part of the questionnaire deals with work life balance of women lawyers. Which was assessed on a scale ranging from 1 = "very dissatisfied" to 5 = "very satisfied". Questionnaire was circulated among women lawyers and the data was collected from 50 respondents.

\section{Chi - Square Test}

In order to find out the relationship between the Marital Status and opinion about the satisfactory level Work life Balance of Women Lawyers.

Null hypothesis Ho: There is no relationship between marital status and work life balance.

Alter native hypothesis H1: There is close relationship between marital status and work life balance.

Table 1

\begin{tabular}{|l|l|l|l|l|}
\hline $\mathbf{O i}$ & $\mathbf{E i}$ & $\mathbf{O i - E i}$ & $(\mathbf{O i}-\mathbf{i}) \mathbf{2}$ & $(\mathbf{O i - E i ) 2 / E i}$ \\
\hline 4 & 1.36 & 2.64 & 6.96 & 5.117 \\
\hline 0 & 2.24 & 2.24 & 5.08 & 2.267 \\
\hline 0 & 0.64 & 0.64 & 0.409 & 0.639 \\
\hline 6 & 2.04 & 3.96 & 15.68 & 7.686 \\
\hline 0 & 3 & 3 & 9 & 3 \\
\hline 0 & 0.96 & 0.96 & 0.92 & 0.958 \\
\hline 2 & 2.72 & -0.72 & 0.51 & 0.187 \\
\hline 4 & 4 & 0 & 0 & 0 \\
\hline 2 & 1.28 & 0.72 & 0.51 & 0.398 \\
\hline 5 & 6.12 & -1.12 & 1.25 & 0.204 \\
\hline 9 & 9 & 0 & 0 & 0 \\
\hline 4 & 2.88 & 1.12 & 1.25 & 0.434 \\
\hline 0 & 4.76 & 4.76 & 22.65 & 4.758 \\
\hline 12 & 7 & 5 & 25 & 3.571 \\
\hline 2 & 2.24 & -0.24 & 0.057 & 0.025 \\
\hline & & & TOTAL & $\mathbf{2 9 . 2 4 4}$ \\
\hline
\end{tabular}

\section{Chi - Square Analysis}

The chi-square test is used to determine whether there is a significant difference between the expected frequencies and the observed frequencies in one or more categories.

$\chi 2=\sum\left(\left(\mathrm{O}\right.\right.$ i-Ei) $\left.{ }^{\wedge} \mathbf{2} / \mathrm{Ei}\right)$

Where, $\mathrm{Oi}=$ Observed frequency; $\mathrm{E} i=$ Expected frequency;

Level of Significance $\quad: 0.05$

Degrees of Freedom $\quad: 8$

Calculated Value $\quad: 29.244$

Critical value $\quad: 15.507$ 


\section{Interpretation}

Since the calculated value is greater than the critical value alternate hypothesis is accepted. So there is significant relationship between marital status \& work life balance.

CHI - SQUARE TEST - In order to find out the relationship between Age and gender related discrimination of Women Lawyers.

Step: 1 Null hypothesis Ho: There is no relationship between Age and gender discrimination. Alter native hypothesis H1: There is close relationship between Age and gender discrimination

Table 2

\begin{tabular}{|l|l|l|l|l|}
\hline $\boldsymbol{O} \boldsymbol{i}$ & $\boldsymbol{E} \boldsymbol{O}$ & $\boldsymbol{O} \mathbf{i}-\mathbf{i}$ & $(\boldsymbol{O} \boldsymbol{i}-\boldsymbol{E} \boldsymbol{i}) \mathbf{2}$ & $(\boldsymbol{O} \boldsymbol{i}-\boldsymbol{E} \boldsymbol{i}) \mathbf{2} \mathbf{E} \boldsymbol{i}$ \\
\hline 0 & 0.52 & -0.52 & 0.27 & 0.52 \\
\hline 1 & 2.08 & -1.08 & 1.166 & 0.56 \\
\hline 3 & 1.82 & 1.18 & 1.39 & 0.76 \\
\hline 5 & 4.68 & 0.32 & 0.102 & 0.021 \\
\hline 4 & 3.9 & 0.1 & 0.01 & 0.002 \\
\hline 0 & 0.4 & 0.4 & 0.16 & 0.4 \\
\hline 2 & 1.6 & 0.4 & 0.16 & 0.1 \\
\hline 1 & 1.4 & 0.4 & 0.16 & 0.114 \\
\hline 4 & 3.6 & 0.4 & 0.16 & 0.04 \\
\hline 3 & 3 & 0 & 0 & 0 \\
\hline 0 & 0.44 & -0.44 & 0.193 & 0.44 \\
\hline 2 & 1.76 & 0.24 & 0.057 & 0.032 \\
\hline 1 & 1.54 & -0.54 & 0.291 & 0.188 \\
\hline 4 & 3.96 & 0.04 & 0.0016 & 0.0004 \\
\hline 4 & 3.3 & 0.7 & 0.49 & 0.148 \\
\hline 2 & 0.64 & 1.36 & 1.849 & 3.418 \\
\hline 3 & 2.56 & 0.44 & 0.193 & 0.075 \\
\hline 2 & 2.24 & 0.24 & 0.057 & 0.025 \\
\hline 5 & 5.76 & 0.76 & 0.577 & 0.332 \\
\hline 4 & 4.8 & 0.8 & 0.64 & 0.133 \\
\hline & & & TOTAL & $\mathbf{7 . 3 0 8 4}$ \\
\hline
\end{tabular}

Chi - Square Analysis

$\chi 2=\sum((\mathrm{Oi}-\mathrm{Ei}) \wedge 2 / \mathrm{Ei})$

Statistical Test

Level of Significance

Degrees of Freedom

: Chi - Square, Test of Independence.

Calculated Value

0.05

Calculated Valuc

$: 15.507$

\section{INTERPRETATION}

Since the critical value is greater than the calculated value null hypothesis is accepted. So there is no significant relationship between Age and gender discrimination.

\section{FINDINGS:}

(1) Table 1 indicates that there is relationship between marital status \& work life balance. Most of the women lawyers feel it difficult to manage their work \& family simultaneously.

(2) Table 2 shows that there is no relationship between age \& gender discriminations. Thus women are been discriminated irrespective of their age and experience. Discrimination exists right from the income level of men and women lawyers, till the post they hold \& the type of cases they handle.

\section{Conclusion}

In conclusion, women increasingly are entering the legal profession, yet they are not located in the same positions as men. Arguments that the mere entry of women must make a difference to the practice of law need to examine the work contexts where different methods might be adopted rather than focusing on the gender of the practitioner. The first step towards making the profession more 'women-friendly' has to be by breaking down the internal barriers caused by the persistence of sex role stereotypes and norms dictating that women should be subordinate to men in public and in private life. While the ambivalence that women feel when trying to balance their traditional domestic roles with their professional role and the male centric approach of the profession itself cannot be gotten rid of overnight, small steps must be taken to make it more feasible for women to be successful in the profession. One such step lies in the Delhi High Court's proposal to set up a crèche for the day care of children of women advocates and court employees. With such moves, it can be said that small 
steps are being taken to make it more viable for women to have a successful legal career; however, these are mere drops in the ocean and much more needs to be done for any significant change to take place.

\section{Books:}

\section{References}

[1]. Hochschild AR (1997) The Time Bind: When Work Becomes Home and Home Becomes Work. Metropolitan Books, New York.

[2]. Hayman J (2005) Psychometric Assessment of an instrument designed to measure work-life balance. Research and Practice in Human Resource Management, 13(1)85-91.

[3]. Hamilton Gordon, Karen, Berry (2006) Understanding the work-life conflict of never-married women without children. Women in Management Review. Bradford, 21(5):393.

[4]. Robbins SP (2005) Organization Behavior, 11th Edition, Prentice Hall, New Jersey,USA. ISBN-81 -203- 2875-2

[5]. MacInnes (2005) Work-Life Balance and the Demand for Reduction in Working Hours: Evidence from the British Social Attitudes Survey. British J. Industrial Relations, London, 43(2):273.

[6]. Dash, Anand, Gangadharan (2012) Perceptions of work-life balance among IT professionals. IUP J. Organizational Behavior, 5165 .

Journals:

[1]. Cynthia Fuchs Epstein et al., "Glass Ceilings and Open Doors: Women's Advancement in the Legal Profession"

[2]. Lisa P fenninger, "Sexual Harassment in the Legal Profession: Workplace Education and Reform, Civil Remedies, and Professional Discipline"

[3]. David L. Chambers, "Accommodation and Satisfaction: Women and Men Lawyers and the Balance of Work and Family"

[4]. "Delhi High Court to get Creche for Lawyers' Tiny Tots" sourced from newshopper.sulekha.com/delhi-high-court-to-get-crechefor-lawyers-tiny-tots_news_933882.htm

[5]. "Women Entering the Legal Profession: Change and Resistance" sourced from www.uk.sagepub.com/upmdata/12634_Chapter5.pdf. 